\title{
REGENERATION POTENTIALS OF NATIVE TREE SPECIES IN THREE NATURAL FORESTS OF SYLHET, BANGLADESH
}

\author{
Haider, M. R., S. Alam and M. Mohiuddin \\ Bangladesh Forest Research Institute, P.O. Box No - 273, Chittagong 4000, Bangladesh
}

\begin{abstract}
Natural regeneration status of native tree species in three natural forests of Moulvibazar, Sylhet Forest Division, Bangladesh was assessed through stratified random sampling method. A total of 70 tree species belonging to 31 families was recorded. Moraceae has the maximum number of species ( 8 species). Myrtaceae has 6 species and Rubiaceae has 5 species while both Euphorbiaceae and Meliaceae have 4 species each. The families Anacardiaceae, Bignoniaceae, Combretaceae, Fagaceae, Lauraceae, Sterculiaceae, Verbenaceae have 3 species each, while Clausiaceae, Mimosaceae and Ternstroemiaceae has 2 species each, and the rest 16 families (viz. Apocynaceae, Aquifoliaceae, Araliaceae, Arecaceae, Bombacaceae, Burseraceae, Caesalpinaceae, Dilleniaceae, Dipterocarpaceae, Elaeocarpaceae, Lythraceae, Myrsinaceae, Polygalaceae, Rutaceae, Tiliaceae, Thymelaeaceae) comprise one species each. Artocarpus chama represents maximum seedlings production per hectare (2,528), followed by Syzygium firmum (1825), Ficus racemosa (1425), Syzygium fruticosum (1033) and Holigarna caustica (917). Biological diversity indices were also calculated which ensure a promising regeneration status of Moulvibazar Natural forests. The percentage distribution of seedlings was maximum $(78.12 \%)$ for $0-50 \mathrm{~cm}$ height range for all species. The numbers of seedling reduced proportionately with height growth indicating the reduction recruitment of seedlings in Moulvibazar natural forests. Artocarpas chama showed maximum $(1.97 \%)$ seedling recruitment. Natural regeneration potential is useful for developing the management plans for effective functioning of Moulvibazar natural forests, Sylhet, Bangladesh.
\end{abstract}

Key words: Diversity indices, regeneration potentials, Moulvibazar natural forests, seedlings recruitment.

\section{INTRODUCTION}

Natural regeneration of the plant species of a forest is essential for conservation and maintenance of biodiversity (Hossain et al. 2004). It helps in the development of plant population of an area over time and space. This is a complex ecological process which involves dispersal of propagating materials, reproduction and establishment of seedlings in relation to environmental factors (Barnes et al. 1998). Biotic and abiotic factors along with disturbance regimes strongly influence the regeneration process, recruitment, species abundance and status of plant species in an ecosystem. Dynamics of soil seed bank, seedlings of forest vegetation and population structure are utmost important factors for the successful natural regeneration. Knowledge base of plant regeneration status helps in developing management options and setting priorities (Zegeye et al. 2011).

Bangladesh has a total of $1.442 \mathrm{~m}$ ha of forest land and natural forest cover is about $1.204 \mathrm{~m}$ ha (Altrell et al. 2007). The natural forests of the country have been under stress of severe biotic and abiotic interferences for the last few decades due to over population, land use changes, inappropriate and poor management practices (Khan et al. 2008). Till today the forest resources of the country are declining in an alarming rate. In the circumstances, it is necessary to enhance the natural regeneration of forest tree species by suitable artificial and natural process for protecting forest flora and maintaining sustainability of yield, goods and services (Haque and Alam 1988). A number of studies that focused on natural regeneration status in different natural forests of Bangladesh provide potential information for many native tree species (Hossain et al. 1999, Miah et al. 1999, Hossain et al. 2004, Motaleb and Hossain 2007, Rahman et al. 2011, Hossain et al. 2013). However, there is little information about the natural forests of Moulvibazar including the Lawachara National Park which is essential for its improvement and sustainable management. Therefore, the study was conducted to evaluate the regeneration status, composition and diversity of the dominant tree species of the Moulvibazar natural forests. 


\section{MATERIAL AND METHODS}

The study was conducted in three locations, namely Lawachara, Adampur (Kalengi) and SreeGobinapur natural forests under Moulvibazar district of Sylhet Forest Division. The study area lies between $24^{0} 30^{\prime}-24^{0} 32^{\prime} \mathrm{N}$ and $91^{0} 37^{\prime}-91^{0} 39^{\prime} \mathrm{E}$ (Feeroz et al.1994). Lawachara is under the Lawachara National park (LNP) a well-known protected area in Bangladesh. The park is a part of West Banugach reserved Forest of Moulvibazar range under Sylhet Forest Division (IRG 2006). The park covers an area of 1250 hectares $\left(1.25 \mathrm{~km}^{2}\right.$ ). Adampur (Kalengi) is a reserve forest under Adampur beat of Rajkandi range and Sree-Gobindpur was a reserve under Moulvibazar range and it was handed over to a private ownership in 1980's. Now, it is under the control of Sree-Gobindpur tea estate and gradually converted the forest into tea gardens. The remaining forest area is about 300 hectares.

The topography of the study area is undulating with gentle slopes and hillocks. These are called tilla and are scattered throughout the forest ranging from 10 to 20 meters in height and rarely 60 to 80 meters. The Manu and the Dholoi rivers exist with numerous streams flow in or around the study area. The soils are dark brown, sandy clay loam of Pliocene origin (Hossain et al. 1989). The climate of the study area is generally worm and humid, weather turns cool in the winter. Temperature varies in an average from minimum $5^{\circ} \mathrm{C}$ in January for a very short period maximum $37.7^{0} \mathrm{C}$ in March. The study area is one of the high rainfall zones of the country and varies approximately from 2400 to $5400 \mathrm{~mm}$ with maximum rainfall bearing in May to September due to monsoon. Humidity is high throughout the year with monthly average humidity varying from 64\% in March to 86\% in June (BMD 2010).

Stratified random quadrat method was applied to determine the regeneration status of Moulvibazar natural forest. A total of 72 permanent sample plots (quadrate), 24 quadrates in each location was laid out in three different locations covering all the aspects and slopes of the hill. Optimum quadrate size was found $3 \mathrm{~m} \times 3 \mathrm{~m}$ and was determined by applying the species area curve of Williams (1991). Within each quadrate, the name and number of seedlings with $\geq 20 \mathrm{~cm}$ in height and saplings of each species were counted with height and recorded for consecutive three years (2010-2012). Data were collected once a year from January to May. The seedlings were identified by local guide in the field and authenticated by the taxonomist of Bangladesh Forest Research Institute and National Herbarium.

The frequency, Relative Frequency (RF), Density, Relative Density (RD), Abundance, Relative Abundance (RA), Relative Dominance (RDo) and Importance Value Index (IVI) of each species were calculated according to Muller-Dombois and Ellenberg (1974), Balslev et al. (1987), and Shukla and Chandal (2007). Plant diversity indices were calculated by using the following equation:

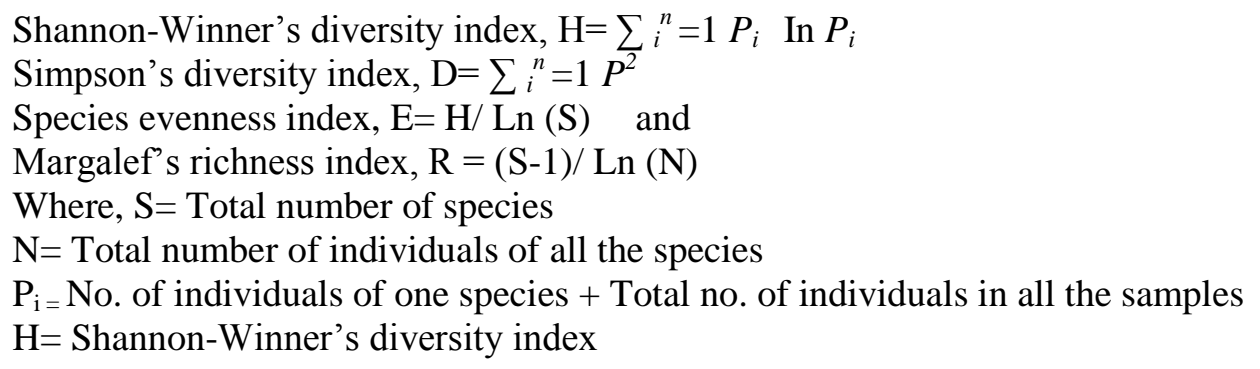

\section{Regenerating tree species composition}

\section{RESULTS AND DISCUSSION}

A total of 70 regenerating tree species belonging to 31 families with 48 genera was recorded from three locations of natural forest area (Table 1). Regeneration was studied for 3 years $(2010,2011$ and 2012). The results revealed that at Lawachara, maximum regeneration was recorded in 2011 (39 species), followed by 31 species in 2012 and 30 species in 2010. In Adampur, highest 36 species was 
recorded in 2011, followed by 31 species in 2012 and 27 species in 2010. At Gobindpur maximum 37 species was recorded in 2011, followed by 32 species in 2010 and 31 species in 2012 (Table 1).

Table 1. Regenerating tree species recorded from three locations of the natural forests of Moulvibazar district in the years 2010, 2011 and 2012.

\begin{tabular}{|c|c|c|c|c|c|c|c|c|c|c|c|}
\hline \multirow[t]{2}{*}{ Family } & \multirow[t]{2}{*}{ Scientific name } & \multirow[t]{2}{*}{ Local name } & \multicolumn{3}{|c|}{ Lawachara } & \multicolumn{3}{|c|}{ Adampur } & \multicolumn{3}{|c|}{ Gobindpur } \\
\hline & & & 10 & 11 & 12 & 10 & 11 & 12 & 10 & 11 & 12 \\
\hline \multirow{3}{*}{ Anacardiaceae } & Holigarna caustica & Jawa & + & + & + & + & + & + & + & + & + \\
\hline & Mangifera sylvatica & Uriam & + & + & - & - & - & - & - & - & - \\
\hline & Spondias pinnata & Amra & - & - & - & - & - & + & - & - & - \\
\hline Apocynaceae & Alstonia scholaris & Chatim & - & - & - & - & + & - & - & + & - \\
\hline Aquifoliaceae & Ilex godajam & Ludh & - & - & - & - & + & - & - & - & - \\
\hline Araliaceae & Trevesia palmata & Bonpapaya & + & + & + & - & - & - & + & + & + \\
\hline Arecaceae & Caryota urens & Bonsupari & - & + & + & - & + & - & - & - & + \\
\hline \multirow{2}{*}{ Bignoniaceae } & Oroxylum indicum & Kanaidinga & - & - & - & - & - & - & + & + & + \\
\hline & Stereospermum colais & Dharmara & - & - & + & - & + & + & - & + & + \\
\hline Bombacaceae & Bombax insigne & Bonsimul & - & - & - & - & - & - & + & - & - \\
\hline Burseraceae & Protium serratum & Gutguttya & + & + & - & - & + & - & - & - & - \\
\hline Caesalpinaceae & Cassia nodosa & Bonsonalu & - & - & - & - & + & - & - & - & - \\
\hline \multirow{2}{*}{ Clausiaceae } & Garcinia xanthochymus & Demgola & - & - & + & - & - & + & - & - & + \\
\hline & G. cowa & Kao & + & + & + & + & + & + & + & + & + \\
\hline \multirow{3}{*}{ Combretaceae } & T. chebula & Haritaki & - & + & - & - & + & + & - & + & + \\
\hline & T. bellirica & Bahera & + & + & - & - & - & + & + & + & - \\
\hline & Terminalia catappa & Katbadam & - & - & + & - & - & - & - & - & - \\
\hline Dilleniaceae & Dillenia pentagyna & Hargaja & + & + & - & - & + & - & - & - & - \\
\hline Dipterocarpaceae & Dipterocarpus turbinatus & Teligarjan & - & - & - & + & - & - & - & - & - \\
\hline Elaeocarpaceae & Elaeocarpus varunna & Bonjalpai & + & + & + & + & + & + & + & + & + \\
\hline \multirow{4}{*}{ Euphorbiaceae } & Aporosa dioica & Kakra & + & + & + & + & + & + & + & + & + \\
\hline & Mallotus albus & Bonmali & - & - & - & - & + & + & - & + & - \\
\hline & Macaranga denticulata & Bongulli & + & + & + & + & + & + & + & + & + \\
\hline & Sapium baccatum & Bolos & - & - & - & + & - & - & + & - & - \\
\hline \multirow{3}{*}{ Fagaceae } & Castanopsis lancifolia & Jatbatna & - & + & - & - & - & - & - & - & - \\
\hline & C. tribuloides & Khamibatna & + & + & + & + & + & + & + & + & + \\
\hline & C. indica & Silbatna & - & + & + & + & + & + & - & + & + \\
\hline \multirow{3}{*}{ Lauraceae } & Cinnaтотит cecidodaphne & Tezbohal & + & + & + & + & + & + & - & + & + \\
\hline & Litsea monopetala & Kukurchita & - & - & - & - & + & - & - & - & + \\
\hline & L. glutinosa & Menda & + & + & - & - & + & + & + & + & + \\
\hline Lythraceae & Lagerstroemia parviflora & Sidajarul & + & + & - & + & - & - & - & - & - \\
\hline \multirow{5}{*}{ Meliaceae } & Amoora wallichii & Lalipitraj & - & + & - & + & - & - & - & + & - \\
\hline & Aphanamixis polystachya & Pitraj & + & + & + & + & + & + & - & + & + \\
\hline & Dysoxylum binectariferum & Bararata & - & - & - & - & - & - & - & + & - \\
\hline & Toona ciliata & Toon & + & + & - & - & + & + & + & + & + \\
\hline & Azedirachta indica & Neem & - & - & - & - & - & - & + & - & - \\
\hline \multirow{2}{*}{ Mimosaceae } & Albizia procera & Sadakoroi & - & - & - & - & - & - & + & - & - \\
\hline & A. chinensis & Chakuakoroi & - & - & - & + & - & - & - & - & \\
\hline \multirow{8}{*}{ Moraceae } & Artocarpus heterophyllus & Kanthal & - & & - & - & - & - & + & + & + \\
\hline & A. lacucha & Borta & + & + & - & - & - & - & - & - & - \\
\hline & A. chama & Chapalish & + & + & + & + & + & + & + & + & + \\
\hline & Ficus clavata & Panidumur & + & + & + & + & + & + & - & + & + \\
\hline & F. hispida & Kakdumur & - & + & - & - & - & - & - & - & - \\
\hline & F. racemosa & Jogdumur & + & + & + & + & + & + & + & + & + \\
\hline & F. auriculata & Laldumur & - & - & + & - & - & + & + & - & - \\
\hline & Streblus asper & Herba & - & - & - & - & + & - & - & + & - \\
\hline Myrsinaceae & Ardisia khasiana thomsoni & Bonkola & - & - & + & - & - & - & + & + & + \\
\hline
\end{tabular}




\begin{tabular}{|c|c|c|c|c|c|c|c|c|c|c|c|}
\hline \multirow{6}{*}{ Myrtaceae } & Syzygium cumini & Kalojam & - & - & - & + & + & + & + & + & + \\
\hline & S. fruticosum & Putijam & + & + & + & + & + & + & + & + & + \\
\hline & S. firmum & Dhakijam & + & + & + & + & + & + & + & + & + \\
\hline & S. macrocarpum & Bonjam & + & + & + & + & + & + & + & + & + \\
\hline & S. syzygoides & Khudijam & - & + & - & - & - & - & - & - & - \\
\hline & S. formosum & Pannyajam & - & - & - & + & - & - & - & + & - \\
\hline Polygalaceae & Xanthophyllum flavescens & Gandi & - & - & - & - & - & - & + & - & - \\
\hline \multirow{5}{*}{ Rubiaceae } & Neolamarkia cadamba & Kadam & - & - & - & + & + & - & - & - & - \\
\hline & Gardenia coronaria & Kannyari & - & - & - & - & + & + & - & - & - \\
\hline & Mitragyna rotundifolia & Bonchampa & - & - & - & + & - & - & - & - & - \\
\hline & M. parvifolia & Dakrom & - & - & - & - & - & - & - & + & - \\
\hline & Adina cordifolia & Haldu & - & - & + & - & - & - & - & - & - \\
\hline Rutaceae & Acronychia pedunculata & Bonjamir & + & + & + & - & + & + & + & + & + \\
\hline \multirow{3}{*}{ Sterculiaceae } & Pterospermum acerifolium & Moskand & + & + & + & - & - & - & - & + & - \\
\hline & Sterculia. foetida & Jorabadam & + & + & + & - & + & + & - & - & - \\
\hline & S. villosa & Udal & + & + & - & - & - & - & + & - & - \\
\hline \multirow{2}{*}{ Theaceae } & Eurya acuminata & Jharu & - & + & + & - & + & - & + & + & + \\
\hline & Schima wallichii & Kanak & - & - & - & - & - & - & + & - & - \\
\hline \multirow{3}{*}{$\begin{array}{l}\text { Tiliaceae } \\
\text { Thymelaeaceae }\end{array}$} & Microcos paniculata & Assar & + & + & + & + & + & + & + & + & + \\
\hline & Aquilaria agallocha & Agar & + & + & + & - & - & - & - & - & - \\
\hline & Callicarpa macrophylla & Bongamar & - & - & - & + & - & + & - & - & - \\
\hline \multirow[t]{2}{*}{ Verbenaceae } & Vitex pubescens & Awal & - & + & - & - & - & - & + & - & - \\
\hline & $V$. peduncularis & Horinagoda & + & + & + & + & + & + & + & + & + \\
\hline
\end{tabular}

The maximum number of species was found in the family Moraceae (8 species) followed by Myrtaceae (6 species), Rubiaceae (5 species), Euphorbiaceae and Meliaceae (4 species each), Anacardiaceae, Bignoniaceae, Combretaceae, Fagaceae, Lauraceae, Sterculiaceae, Verbenaceae (3 species each), Clausiaceae, Mimosaceae and Ternstroemiaceae (2 species each) and rest 16 families comprising one species each (Table 1). Results also reveal that diversity of regenerating tree species vary from location to location and also with the year. However, average number of regenerating tree species among the locations ranged from 31 to 33 species with highest 33 species in both Lawachara and Gobindpur. The composition and richness of understorey tree species are different and are seemingly due to their different responses to abiotic factors such as light, nutrient availability, water availability, wind and temperature (Laska 1997, Sevenning 2000, Siebert 2002). It is apparent from the present study that along with abiotic factors anthropogenic factors also influence the regenerating species composition and richness.

\section{Natural regeneration trends}

The present study recorded 70 regenerating tree species belonging to 31 families with average seedlings of 16,833 per hectare. The results reveal that number of seedlings varied from location to location, year to year and also species to species. At Lawachara, average seedlings were 21,875 per ha, minimum 12,875 seedlings in 2010 and maximum 29,725 seedlings/ha in 2012. In Adampur average seedlings were 12,950/ha, with minimum 9,075 seedlings in 2010 and maximum 16,225 seedlings in 2012. But, in Gobindpur average seedlings were 15,675/ha, minimum 11,600 seedlings in 2010 and maximum 20,375 seedlings in 2011 (Fig. 1). Result also reveals increasing trend of regeneration in each year irrespective of location except at Gobindpur in 2012. It was due to incidence of fire in the area. It indicates the regeneration potentials of the forests. 


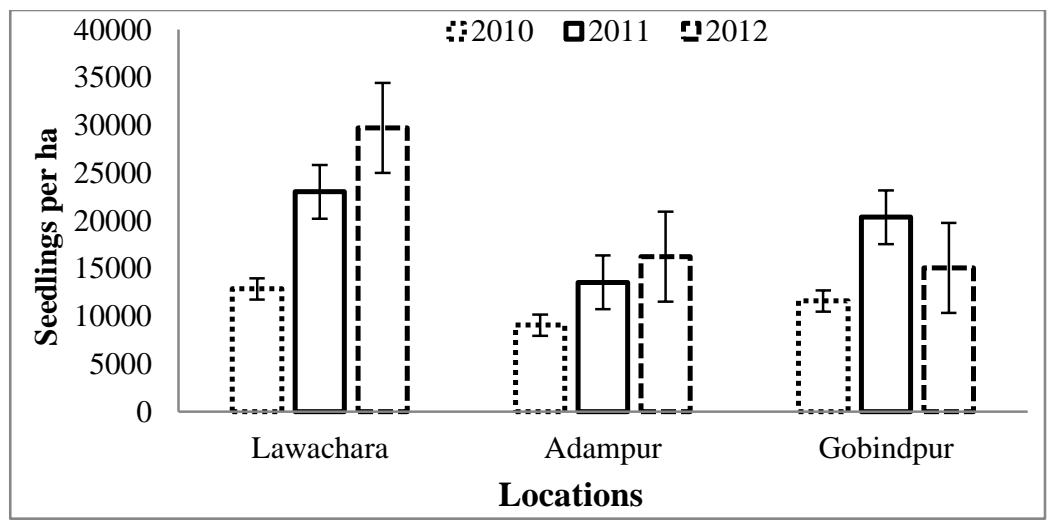

Fig. 1. Regeneration trends of seedlings (per hectare) in three locations of the natural forests of Moulvibazar district in the years 2010, 2011 and 2012.

Number of regenerating tree species with IVI

The study recorded 70 regenerating tree species in Moulvibazar natural forest. Among the regenerating tree species average highest number of seedlings was found 2558 per hectare for Artocapus chama followed by Syzygium firmum (1825), Ficus racemosa (1425), Syzygium fruticosum (1033), Haligarna caustica ((917), Sygygium macrocarpum (825) and Garcinia cowa (700). The lowest number of seedlings per hectare (25) was found for Microcos paniculata, Sterculia foetida, Aphanamixis polystachya and Trema orientalis. The maximum Importance Value Index (IVI) was calculated for Artocarpus chama (21.60), followed by Syzygium firmum (20.54), Ficus racemosa, Syzygium. macrocarpum (13.82), Castonopsis tribuloides (12.29) and Garcinia cowa (11.26). The minimum IVI (1.76) was found for Albizia procera, Trema orientalis, Aquilaria malaccences, Ilex godajam, Bombex insigne and Cassia nodosa. Seedlings per hectare and Importance Value Index (IVI) of 30 regenerating tree species in Moulvibazar natural forest was given in Table 2.

Table 2. Seedlings per hectare and IVI of 30 dominant regenerating tree species in Moulvibazar natural forest.

\begin{tabular}{lcccc|cccc}
\hline \multirow{2}{*}{ Scientific Name } & \multicolumn{4}{c|}{ Seedling per hectare } & \multicolumn{4}{c}{ Importance Value Index (IVI) } \\
\cline { 2 - 9 } & L & A & G & Avg. & L & A & G & Avg. \\
\hline Albizia chinensis & - & 350 & - & 117 & - & 9.37 & - & 3.12 \\
Aphanamixis polystachya & 50 & 650 & 825 & 508 & 1.88 & 10.53 & 8.92 & 7.11 \\
Aporosa dioica & 375 & 50 & 650 & 358 & 6.23 & 1.54 & 8.05 & 5.27 \\
Artocarpus chama & 6375 & 175 & 1125 & 2558 & 46.43 & 5.52 & 12.84 & 21.60 \\
Artocarpus heterophyllus & - & 75 & 375 & 150 & - & 3.34 & 7.24 & 3.53 \\
Castanopsis indica & 850 & 375 & 775 & 667 & 10.87 & 9.27 & 10.39 & 10.18 \\
Castanopsis tribuloides & 1300 & 575 & 425 & 767 & 17.73 & 12.18 & 6.95 & 12.29 \\
Cinnamomum & 125 & 1025 & 200 & 450 & 3.33 & 12.68 & 4.74 & 6.92 \\
cecidodaphne & & & & & & & & \\
Elaeocarpus varunna & 100 & 75 & 175 & 117 & 2.82 & 3.34 & 4.99 & 3.72 \\
Ficus clavata & 500 & 25 & 125 & 217 & 10.35 & 1.73 & 3.23 & 5.10 \\
Ficus hispida & 1025 & - & - & 342 & 20.23 & - & - & 6.74 \\
Ficus racemosa & 2575 & 150 & 1550 & 1425 & 23.05 & 5.13 & 16.85 & 15.01 \\
Garcinia cowa & 375 & 425 & 1300 & 700 & 8.19 & 10.45 & 15.13 & 11.26 \\
Holigarna caustica & 300 & 700 & 1750 & 917 & 5.72 & 10.74 & 12.71 & 9.72 \\
Ilex godajam & - & 500 & - & 167 & - & 9.74 & - & 3.25 \\
Macaranga denticulata & 1500 & - & 325 & 608 & 16.22 & - & 5.81 & 7.34 \\
Mallotus albus & - & 375 & 100 & 158 & - & 8.65 & 3.15 & 3.93 \\
\hline
\end{tabular}




\begin{tabular}{lcccc|cccc}
\hline Microcos paniculata & 75 & 250 & 375 & 233 & 2.35 & 8.97 & 6.79 & 6.04 \\
Mitragyna rotundifolia. & - & 2000 & - & 667 & - & 26.33 & - & 8.78 \\
Pterospermum acerifolium & 250 & - & 150 & 133 & 5.65 & - & 4.25 & 3.30 \\
Stereospermum colais & - & 75 & 325 & 133 & - & 2.34 & 6.83 & 3.06 \\
Sygygium macrocarpum & 650 & 700 & 1125 & 825 & 8.79 & 14.69 & 17.97 & 13.82 \\
Syzygium cumini & - & 225 & 250 & 158 & - & 8.17 & 6.84 & 5.00 \\
Syzygium firmum & 575 & 1475 & 3425 & 1825 & 8.54 & 22.59 & 30.49 & 20.54 \\
Syzygium formosum & - & - & 750 & 250 & - & - & 10.68 & 3.56 \\
Syzygium fruticosum & 125 & 1100 & 1875 & 1033 & 3.33 & 18.21 & 18.99 & 13.51 \\
Terminalia chebula & 25 & 750 & 200 & 325 & 1.41 & 12.69 & 5.61 & 6.57 \\
Toona ciliata & 300 & 125 & 600 & 342 & 5.58 & 4.95 & 8.67 & 6.40 \\
Trevesia palmata & 1400 & - & 500 & 633 & 16.16 & - & 7.81 & 7.99 \\
Vitex peduncularis & 475 & 325 & 950 & 583 & 8.15 & 7.86 & 12.99 & 9.67 \\
\hline
\end{tabular}

Here, $\mathrm{L}=$ Lawachara, $\mathrm{A}=$ Adampur, $\mathrm{G}=$ Gobindpur

\section{Biological diversity indices}

Different biological indices, such as Shannon-Winner diversity index (H), Simpson's diversity index (D), Species evenness index (E) and Margalef's richness index (R) were evaluated for Moulvibazar natural forest to reveal the natural regeneration status of recorded plant species (Table 3). Margalef's index (5.645) for regenerating plant species indicates higher species richness in Moulvibazar natural forests. On the other hand, Shannon-Winner diversity index (3.22) and Simpson's diversity index (0.065) depict higher diversity in regenerating plant species. A small variation in the plant community was also depicting by higher value of species evenness ( 0.859 out of 1$)$. The different diversity indices of the regenerating plants are represented in Table 3.

Table 3. Different diversity indices for regenerating plant species in Moulvibazar natural forests.

\begin{tabular}{lcccc}
\hline Locations & $\begin{array}{c}\text { Shannon-Winner } \\
\text { diversity index (H) }\end{array}$ & $\begin{array}{c}\text { Simpson's diversity } \\
\text { index (D) }\end{array}$ & $\begin{array}{c}\text { Species evenness } \\
\text { index (E) }\end{array}$ & $\begin{array}{c}\text { Margalef's richness } \\
\text { index (R) }\end{array}$ \\
\hline Lawachara & 3.049 & 0.065 & 0.852 & 5.560 \\
Adampur & 3.121 & 0.065 & 0.846 & 5.815 \\
Gobindpur & 3.049 & 0.065 & 0.851 & 5.560 \\
\hline Mean & 3.073 & 0.065 & 0.849 & 5.645 \\
\hline
\end{tabular}

Distributions of seedlings in different height classes

Regenerates below $251 \mathrm{~cm}$ in height were considered as seedlings. The percentage distribution of all seedlings of all species into different height $(\mathrm{cm})$ classes is provided in Figure 2. It was evident that maximum (78.12\%) seedlings were within the range of $0-50 \mathrm{~cm}$ height classes, whereas, only $1.44 \%$ seedlings were found $201-250 \mathrm{~cm}$ height classes. It indicates the poor survival of seedlings probably resulting from both biotic and abiotic interferences.

\section{Recruitment of the seedlings}

The recruitment of seedlings is important in a natural forest to determine the structure and sustainability of the forest. Data on regeneration were collected for consecutive three years (2010, 2011 and 2012). However, seedling recruitment percentage of the species was evaluated for the year 2011 only, keeping the similarities as species diversity and density were evaluated for the same year. Comparative recruitment percentages of major dominating seedlings with the corresponding tree stem/ha are shown in Table 3. Artocapus chama had maximum $1.79 \%$ seedling recruitment percentage followed by Syzygium firmum (1.86\%), and Ficus racemosa (1.54\%). 


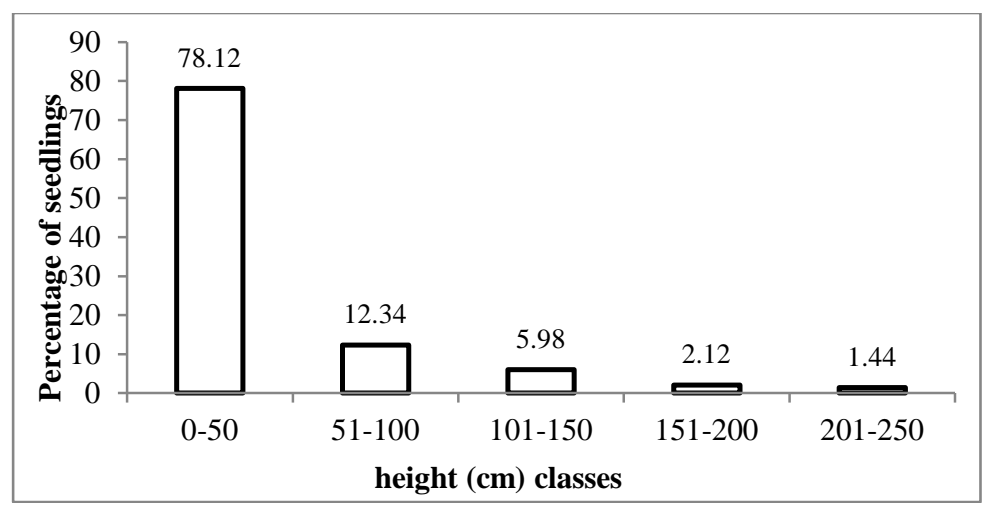

Fig. 2. Percentage distribution of all seedlings in different height $(\mathrm{cm})$ classes.

ANOVA showed that recruitment percentage with seedlings/ha is significant at $\mathrm{F}=5.21, \mathrm{P}<0.01$ level. Moreover, recruitment percentage with stem/ha is also significant at $\mathrm{F}=3.47, \mathrm{P}<0.01$ level, that are similar to the findings of Rahman (2002), Arif (2003), Rahman et al. (2011) and Reddy et al. (2011). There is a wide gap between number of natural regeneration and their successful recruitment to only a few poles and trees. This might be partly due to lacking of silvicultural requirement of the individual species and mostly biotic interferences particularly in Adampur and Gobindpur areas of Moulvibazar natural forests.

Table 4. Percentage recruitment of 10 major regenerating tree species in relation to trees/ha and seedlings/ha at Moulvibazar natural forests.

\begin{tabular}{lccc}
\hline Scientific name & Tree stem/ha & Seedlings/ha & Recruitment (\%) \\
\hline Artocarpus chama & 51 & 2585 & 1.97 \\
Syzygium firmum & 34 & 1825 & 1.86 \\
Ficus racemosa & 22 & 1425 & 1.54 \\
Syzygium fruticosum & 9 & 1033 & 0.87 \\
Haligarna caustica & 4 & 917 & 0.44 \\
Syzygium macrocarpum & 2 & 825 & 0.24 \\
Garcinia cowa & 16 & 767 & 2.09 \\
Castanopsis tribulodes & 9 & 700 & 1.29 \\
C. indica & 5 & 667 & 0.75 \\
Mitragyna rotundifolia & 3 & 667 & 0.45 \\
\hline
\end{tabular}

The conservation measures of biological diversity should be based on regeneration potentials of plant species (Verma et al. 1999). It is an important indicator for evaluating the overall situation of a forest ecosystem (Rahman et al. 2011). In the present study 70 regenerating tree species belonging to 31 families with 48 genera were recorded from three locations of Moulvibazar natural forest and the number of species is comparatively higher than earlier reports on similar natural forests of Bangladesh. Hossain et al. (2004) reported 64 regenerating tree species in the natural forest of Chittagong South Forest Division. Motaleb and Hossain (2007) reported 29 regenerating tree species from the semievergreen forest of Chittagong South Forest Division. Rahman et al. (2011) stated 55 regenerating plant species in Khadimnagar National Park and Tilagarh Eco-Park. The higher regenerating status in Moulvibazar natural forests might be due to one of the protected areas was kept under the study which is Lawachara National Park and have minimum human interference. This might be the main cause of higher number of seedlings in the initial stage of seedling development. The families Moraceae, Myrtaceae, Rubiaceae, Euphorbiaceae and Meliaceae showed the higher regeneration potentials due to 
maximum seed dispersal capability and favorable climatic conditions for natural regeneration. Artocapus chama, Syzygium firmum, Ficus racemosa, Syzygium fruticosum, Holigarna caustica, Syzygium macrocarpum and Garcinia cowa showed the dominant regeneration. This is because of their profuse seed production and suitable climatic condition for successful regeneration.

The diversity indices of the study show promising regeneration potential in Moulvibazar natural forest in comparison to the diversity indices reported by Rahman et al. (2011) from the biodiversity conservation areas of Northeastern Bangladesh. They reported 0.03 for Simpson's diversity index, species richness index 4.92, Shannon-Winner diversity index 3.62, and Species evenness index 2.26. There is a tremendous pressure on Moulvibazar natural forests as forest dependent local communities are residing around the natural forests and conversion of natural forests into tea garden is common. However, recent co-management initiatives and conservation program with the participation of local people at Lawachara National Park, a protected area in the study area seem to be promising initiatives for biodiversity conservation.

Present study reveals that Moulvibazar natural forests possess higher regeneration potentials for many economically and ecologically important tree species. However, still there are many causes which may be critical for the occurrence and establishment of natural regeneration in Moulvibazar natural forests. Thus the concern authority must be careful for the implementation of the conservation measures and enhance effective co-management and protection program involving the local people to ensure fruitful conservation of Moulvibazar natural forests. The species that have low IVI should be given priority in conservation program. Protection and aided natural regeneration (ANR) may be another alternative option for effective natural regeneration and conservation of Moulvibazar natural forests instead of converting these species rich natural forests to artificial plantations.

\section{ACKNOWLEDGEMENTS}

The authors cordially acknowledge the staff member of Lawachara Silviculture Research Station of Bangladesh Forest Research Institute for their assistance during the field work. We also recognize M. Akhter Hossain, Assistant Professor, Institute of Forestry and Environmental Sciences, University of Chittagong for helping in statistical analysis.

\section{REFERENCES}

Altrell, D., M. Saket, L. Lyckeback, M. Piazza, I. U. Ahmad, H. Banik, M. A. A. Hossain and R. M. Chowdhury. 2007. National forest and tree resources assessment 2005-2007. Bangladesh Forest Department, Ministry of Environment and Forest: Bangladesh Space Research and Remote Sensing Organization, Ministry of Defense and Food and Agricultural Organization of the United Nations. $192 \mathrm{pp}$.

Arif, M. S. 2003. Tree species diversity and regeneration status in Fulchari forest reserve of Cox's Bazar (north) Forest Division, Bangladesh. M. Sc. Thesis. Institute of Forestry and Environmental Sciences, University of Chittagong, Chittagong. 109 pp.

Balslev, H., J. Luteyn, B. Ollgard and L. B. Holm-Nelson. 1987. Composition and structure of adjacent unflooded and floodplain forest in Amazonian Ecuador. Opera Botanica. 92: 37-57.

Barnes, B. V., D. R. Zak, S. R. Denton and S. H. Spurr. 1998. Forest Ecology. 4th ed. John Wiley and Sons, New York. 792 pp.

BMD (Bangladesh Metrological Department). 2010. Agargoan, Dhaka, Bangladesh.

Feroz, M. M., A. M. Islam and M. M. Kabir. 1994. Food and feeding behavior of hoolock gibbon 
(Hylobates hoolock), capped langur (Presbytis pileata) and pigtailed macaque (Macaca nemastrima) of Lawachara. Bangladesh J. Zool. 22(2): 123-132.

Haque, S. M. and M. S. Alam. 1988. Some aspects of practicing clear-felling followed by artificial regeneration system in Cox's bazaar Forest Division, Chittagong. Chittagong Univ. Stud. Part II. 12(2): 87-95.

Hossain, M. A., M. K. Hossain and M. D. Hossain. 2013. Natural Regeneration Potentials of Native Tree Species in Dudhpukuria-Dophachari Wildlife Sanctuary of Chittagong, Bangladesh. Bangladesh J. Forest Sci. 33(2): 15-25.

Hossain, M. K., Q. N. Islam, S. A. Islam, M. Tarafder, M. Zashimuddin and A. Ahmed. 1989. Assistance to the Second Agricultural Project: Bangladesh Status Report on the activities of the Silviculture Research Division, BFRI, Chittagong. Working Paper No. 6. FAO: DP/BGD/83/101. $20 \mathrm{pp}$.

Hossain, M. K., M. L. Rahman, A. T. M. R. Haque and M. K. Alam. 2004. Comparative regeneration status in natural forest and enrichment plantations of Chittagong (South) forest division, Bangladesh. J. Forestry Res. 15(4): 255-260.

Hossain, M. K., A. K. Azad and M. K. Alam. 1999. Assessment of Natural Regeneration status in a mixed tropical forest at Kaptai of Chittagong Hill Tracts (south) Forest Division. Chittagong Univ. J. Sci. 23(1): 73-79.

IRG 2006. Management plans for Lawachara National Park. International Resource Group, Washington D.C., USA, pp. 4-13.

Khan, S. M. M. H., A. Nishat and R. Haque. 2008. Biodiversity Conservation in Bangladesh. In: Ahmed, Z. U., Z.N.T. Begum, M. A. Hassan, M. Khondaker, S. M. H. Kabir, M. Ahmed, A. T. A. Ahmed, A. K. A. Rahman and E. U. Haque (eds.). Encyclopidia of Flora and Fauna of Bangladesh. Vol. 1. Asiatic Society of Bangladesh, Dhaka, pp. 9-19.

Laska, M. S. 1997. Structure of understory shrub assemblages in adjacent secondary forest and old growth tropical wet forest, Costa Rica. Biotropica. 29: 29-37.

Miah, M. D., M. F. Uddin and M. K. Bhuiyan. 1999. Study on the natural regeneration of Pitraj (Aphanamixis polystachya Wall. and Parker) in the plantations of Chittagong University Campus. Chittagong Univ. J. Sci. 23(2): 125-127.

Motaleb, M. A. and M. K. Hossain. 2007. Study on the natural regeneration of a semi-evergreen forest of Chittagong (South) Forest Division, Bangladesh. J. Forestry Environ. 5: 95-101.

Muller-Dombois, D. and H. Ellenberg. 1974. Aims and Methods of Vegetation Ecology. John Wiley and Sons, New York. 547 pp.

Rahman, M. H., M. A. S. Khan, B. Roy and M. J. Fardusi. 2011. Assessment of natural regeneration status and diversity of tree species in the biodiversity conservation areas of northeastern Bangladesh. J. Forestry Res. 22(4): 551-559.

Rahman, M. L. 2002. Floristic composition, distribution, diversity and regeneration of tropical rain forest of Chittagong (South) Forest Division. M. Sc. thesis. Institute of Forestry and Environmental Sciences, University of Chittagong, Chittagong, Bangladesh. 116 pp. 
Reddy C. S., B. Shilpa, A. Giriraj and P. Chiranjibi. 2011. Structure and floristic composition of tree stand in tropical forest in the Eastern Ghats of Northern Andhra Pradesh, India. J. Forestry Res. 22(4): 491-500.

Sevenning, J. C. 2000. Small canopy gaps influence plant distribution in the rain forest understory. Biotropica. 32: 252-261.

Shukla, R. S. and P. S. Chandel. 2007. A text book of Plant Ecology. S. Chand and Company (Pvt.) Ltd. Ram Nagar, New Delhi, India. 544 pp.

Siebert, S. 2002. From shade to sun grown perennial crops in Sulawesi, Indonesia: Implication for biodiversity conservation and soil fertility. Biodvers. Conserv. 11: 1889-1902.

Verma, R. K., D. K. Shadangi and N. G. Totey. 1999. Species diversity under plantation raised on a degraded land. The Malaysian Forester. 62: 96-106.

Williams, G. 1991. Techniques and field works in Ecology. Collins Educational Publishers, London, UK, $156 \mathrm{pp}$.

Zegeye, H., D. Teketay and E. Kelbessa. 2011. Diversity, regeneration status of woody species in Tara Gedam Abebaye forests, northwestern Ethiopia. J. Forestry Res. 22(3): 315-328. 